\title{
テレビジョン・ホログラフィ干渉法を用いた 電解めっき膜の内部応力の弚の場測定*
}

\author{
格内敏*1, 高木 將 裕*2, 福室 直 樹*3 \\ 八重 真 治*3, 松田均*3
}

\section{In-situ Measurement of Internal Stress in Electro Deposits by Television Holographic Interferometry}

\author{
Satoshi KAKUNAI*4, Masahiro TAKAKI, Naoki FUKUMURO, \\ Shinji YAE and Hitoshi MATSUDA \\ ${ }^{* 4}$ Department of Mechanical and System Engineering, Graduate School of Engineering, University of Hyogo, \\ 2167 Shosha, Himeji-shi, Hyogo, 671-2201 Japan
}

\begin{abstract}
Electro deposition technology has been utilized widely in various industries. However, the internal stress generated in the plated film during deposition often results in peeling and crack of the thin film. The investigation of generation mechanism of the internal stress is indispensable for improving the plating film. Measurements of internal stress are required during the early stages of film growth. In this study, TV holographic interferometry, which can capture holographic images at TV frame rates, was used to sensitively measure with the accuracy of $\lambda / 2$ the deflection of the cantilever beam during the deposition on the substrate. Internal stress is calculated $i n-s i t u$ by substituting the deformation date in Stoney's equation. In this experiment, to examine the influence of the substrate on internal stress of electroplating, the epitaxial growth of plating was compared with the plating growth on an amorphous substrate. Next, internal stress was measured in various plating $(\mathrm{Zn}, \mathrm{Cu}$ and $\mathrm{Ni}$ ) without the additive. The generation mechanism of the internal stress was considered by the surface morphology (SEM) and the cross-sectional (TEM) observation of the plating film. The main results are as follows. 1) Internal stress during the early stage of film growth changes greatly on the surface of amorphous substrate compared with the epitaxial growth. But, the difference of both becomes small as the film grows up. 2) In general, internal stress rapidly changes in the initial stage of film growth, and changes gradually afterwards. 3) The compression stress is generated in $\mathrm{Zn}$ plating, the tensile stress is generated in $\mathrm{Ni}$ plating and in $\mathrm{Cu}$ plating, a tensile stress is generated in the initial stage of film growth, which immediately changes to compressive stress.
\end{abstract}

Key Words : Experimental Stress Analysis, Television Holography, In-situ Measurement, Electro Deposits, Stoney, Internal Stress, Cantilever Beam, Zn Plating, Cu Plating, Ni Plating

\section{1. 粕 言}

電解めつき技術は航空産業, エレクトロニクス産業, 貴金属製品，雑貨など様々な分野で使われている. 一 般には亜鉛 $(\mathrm{Zn})$, 銅 $(\mathrm{Cu})$, ニッケル $(\mathrm{Ni})$, クロム $(\mathrm{Cr})$ の めつき膜が知られており，各めつき膜の特性を活かし て用いられている(1) ${ }^{(3)}$. しかし，めっき膜生成中に生 じる内部応力により，膜のはく離やひひ割れなどの欠 陷，密着性低下といった問題が起こる．良質なめっき 膜生成のために内部応力の制御力法が求められ，多く の研究がなされてきたが(4)(5), 内部応力の発生メカニズ ムについての充分な解明はなされていない，一方，は

\footnotetext{
* 原稿受付 2009 年 6 月 26 日.

*1 正員, 兵庫県立大学大学院工学研究科 (雭671-2201 姫路市 書写 2176)

*2 正員, 川崎重工業(株) (焉650-8670 神戸市中央区東川崎町 3-1-1).

*3 兵庫県立大学大学院工学研究科(踿671-2201 姫路市書写 2167).

E-mail : kakunai@eng.u-hyogo.ac.jp
}

りのたわみ測定により薄膜の内部志力を算出する方法 には, 静電容量型のギャップセンサー(の)(7), 光てこ(8), 干渉言(9)などを用いて測定が行われてきた。しかし，

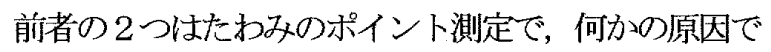
はりがねじれると䛊差を含む。 また，後者の方法では めつき浴中の基板のたわみを，その場で連続的に検出 するには適さない。

著者らは，これまでに無電解めつき浴を使った基礎 的な実験によって，めっき膜生成中の内部応力の挙動 を調べてきだ(10)(11). 実験にはテレビジョン(TV)ホログ ラフィ干渉法 ${ }^{(12)}$ を用いて，めつき膜生成時の片持ちは りのたわみを非接触かつ高精度に測定して，めつき膜 の内部応力を評価した. 本手法では, めっき膜生成直 後からのめつき浴中のはりの変形举動について, 変形 方向を判別しながら連続的に測定が可能である．また 干涉縞パターンを用いた全視野測定法のため，想定外 の干涉縞パターンを持つ実験データについては, 確実 
に除外でき，その原因についての考察む可能である. 本報告では電解めつき膜の初期内部応力の発生举動に ついて，TV ホログラフィによる測定とめっき膜の表 面・断面の詳細な観察を通して考察を試みた. 実験で は，はじめに基板表面の方向性が成膜中の内部応力に 与える影響を調べた. 前処理としてアモルファス膜(無 電解 Ni-P めっき膜）を施した銅基板之，そのままの基 板を準備し，それぞれについて Zn 電解めっき膜を生 成して内部応力を測定した. その結果, アモルファス 膜と素地の基板では，前者の方が初期内部応力に大き な変化が見られた。 しかし，膜厚が大きくなるにした がい，両者注同じような内部応力の值に近づいた。 次 にアモルファス層を持つ銅基板について, Zn, Niおよ $ひ ゙ \mathrm{Cu}$ の電解めっき膜における内部灾力の変化と, 走 查型電子顕微鏡(SEM) と透過型電子顕微鏡(TEM)によ るめっき膜の表面と断面観察功，内部応力の発生入 カニズムについて考察した。

\section{2. 実験方法}

\section{$2 \cdot 1$ テレビジョン・ホログラフィ干渉法 TV} ホログラフィ干渉法では, 簡単な光学系と CCD カメ ラおよびコンピュータの構成によって, 物体の変形パ ターンをTVレートで取得することができる. 片持ち はりの片面にめっき膜が生成されると, その内部応力 によって基板がわずかにたわむ．たわみ量はTVホ口 グラフィ干渉法によって精度良く, また変形方向を判 別して，連続的にその場測定されて自由端のたわみ量 が測定される.このたわみ量を基に, Stoney 等の式 ${ }^{(13)}$ (15)から成膜中の内部応力を算出する.

実験装置の概略を図 1 に示す.Ar+レーザ光源から照 射されたレーザ光は，ビーム・スプリッタで物体光之 参照光に分けられ，参照光は CCD カメラ前のハーフ ミラーによってカメラに入射する.一方,物体照明光は 物体の変形方向を判別するために圧電素子 (PZT ; Piezoelectric transducer) に取付けられたミラーを介して, めっき浴中の片持ちはりを照明する. 片持ちはりで反 射した物体の変形(位相)情報であるスペックルパター ンは, ビーム・スプリッタを通して参照光と共にCCD カメラに記録される.なお，はりのたわみによるスペッ クルパターンの変化は, 一定の時間間隔ごとにコンピ エータに蓄積した.その後,任意のフレーム間隔で $2 つ$ のスペックルパターンを取り出し, その差を計算して ホログラフィ干涉縞を得る. 干涉縞は使用光源の波長 オーダの精度で, その変形パターンを表す。

図2に物体の変形と干涉編の関係走示寸。なお, 図 中の物体面は後述の片持ちはりのコーティング面に相
当する. 物体上の 1 点 $\mathrm{p} か ゙ \mathrm{p}$ に変位し，その変位心゙ク トルを d と寸る. $\mathrm{p}$ 点を照明するレーザ光の方向を示 寸単位べクトルを $\boldsymbol{S}_{i}, \mathrm{p}$ 点を観察する方向を示す単位 ベクトルを $S_{0}$, 使用光源の波長を入とすると, $\mathrm{p}$ 点の変 位による光路長差はざクトル $\left(\boldsymbol{S}_{0}-\boldsymbol{S}_{i}\right)$ と変位べクトル $d$ との内積で与えられる.すなわち，変位による光路長 差は図 2 の照明方向と観察方向を 2 等分するベクトル $\boldsymbol{M} \sim \boldsymbol{d}$ の正射影 $\boldsymbol{d}$ に等しい：したがって，変位によ る位相変化中は次式となる。

$$
\phi=\frac{2 \pi}{\lambda} \boldsymbol{d} \cdot\left(\boldsymbol{S}_{i}-S_{0}\right)
$$

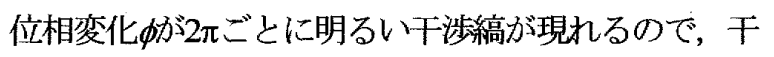
涉縞の次数を数えることにより $\phi$ が求まる. $S_{i}, S_{0}$ は光 学系で決まるので, 変位ベクトル $\boldsymbol{d}$ が決定できる. 本 実験光学系では，片持ちはりの法線方向に対する面外 成分は， 1 縞あたり約 $0.3 \mu \mathrm{m}$ の変位量を表す.

2 -2 変形方向の判別 めつき膜の内部応力が压 縮または引張によって, 片持ちはりの変形方向が異な る. 本実験では片持ちはりの変形方向を判別するため

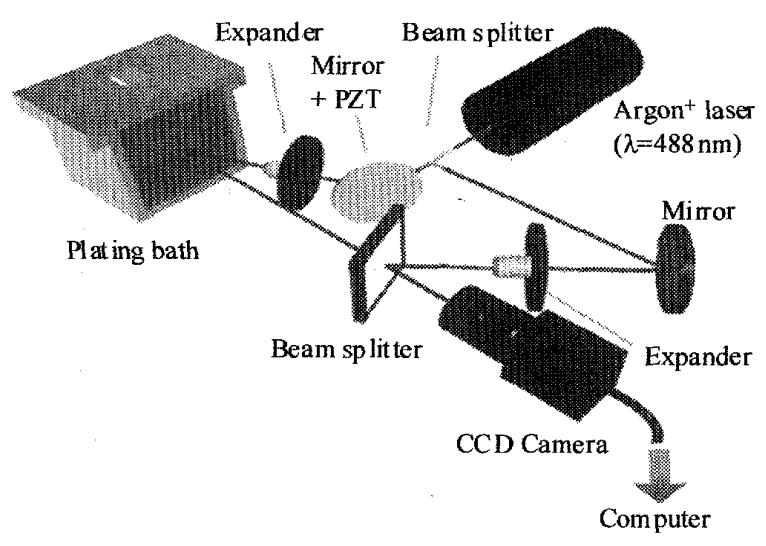

Fig.1 Optical apparatus for TV holographic interferometry

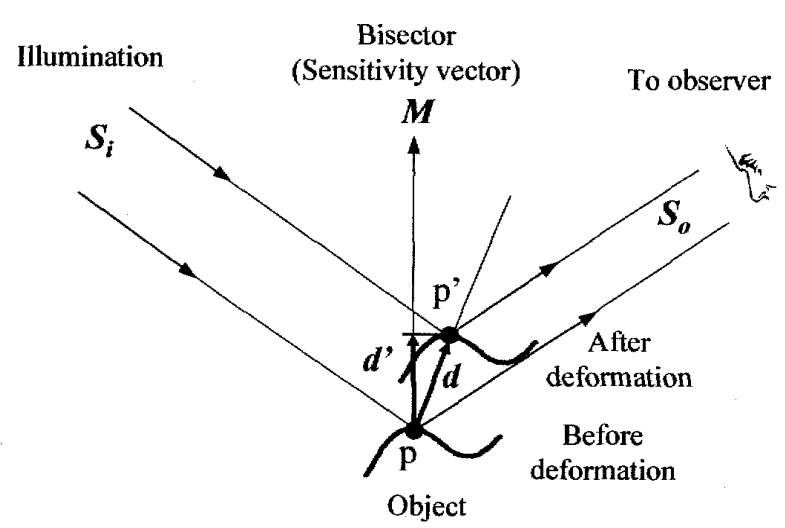

Fig2 Geometry for calculating the optical path length due to displacement vector $d$ 
に変形パターンの記録と同時に, PZT によりミラーに 正負の方向に既知量の微小変化を与え, その光路長を 変化させて記録した. 図 3 に PZT+ミラーによる物体 照射光の光路長の変化方法を示す．PZT の動作はカメ ラの撮影と連動してプログラムにより制御寸る．はじ め0 位置で撮影し,その後 $30 \mathrm{~m}$ 秒後に+位置，一位置にそ れぞれ既知量だけ動かして撮影する。この一連の撮影 を1 セットとしており，0位置での撮影から 1 秒後に 次の撮影の1セットが始まる.これを繰り返し取得し ていくことで，測定と同時に変形方向の半別も可能に した. いま, 0 位置と+位置の光路差を $\mathrm{L}_{1}, 0$ 位置と位置の光路差索 $\mathrm{L}_{2}$, レーザ光の波長を $\lambda$ とすると, $\mathrm{L}_{1}$, $\mathrm{L}_{2}$ が共に $\mathrm{n} \lambda 2$ ( $\mathrm{n}$ は整数）を満をすときは，光路長は 変わるが位相が揃うので干涉縞に変化が見られない． そこで：ミラーに取り付けた PZTをさの方向にそれぞ れ異なる量だけ微小移動させ，光路長を入/2以下で式 (2)のように変化させる.

$$
\begin{array}{ll}
L_{1}=\frac{n \lambda}{2}+a & (0<a<\lambda / 2) \\
L_{2}=\frac{n \lambda}{2}+b & (0<b<\lambda / 2)
\end{array}
$$

式中の $\mathrm{a}, \mathrm{b}(\mathrm{a} \neq \mathrm{b})$ はミラー移動による光路長変化を示 す。このとき図4(a),(b)に示寸ように，片持ちはりの引 張，土縮方向の変位に対する干涉縞が，それぞれ逆方 向に僅か䔟動するため，これよりはりの変位方向の 判断をおこなう。

\section{2 -3 電解めっきと内部応力の算出方法 害験に} 用いた片持ちはりは純銅製（Specialty testing \& development $\mathrm{Co}, \mathrm{INC}$ ) で,長さ $75 \mathrm{~mm}$,幅 $5 \mathrm{~mm}$, 厚さ $0.05 \mathrm{~mm}$ の薄片からなり,片面にはめっき膜が生成され ないようにコーティングが施されている.スペックル パターンはコーティング面で記録した. 電解めっきは 図1のめつき浴槽を拡大して示す図5においておこな った. 陽極にはチタンを白金でコーティングした不溶 性の網目状基板を，陰極には銅基板を設置した．電流 值は $50 \mathrm{~mA}$ とし, 実験室の温度は常時 $25^{\circ} \mathrm{C}$ 亿保った。

めっき膜による片持ちはりの長手方向に生じる内部 応力 $(\sigma)$ は, 片持ちはりのたわみ( 等の式 ${ }^{(13)}$ (15) より算出した.

$$
\sigma=\frac{E T^{2} \delta}{3 L^{2} D(1-v)}
$$

ここで, $E=107.9 \mathrm{GPa}$ : 基板の弾性保数, $T=0.05 \mathrm{~mm}$ : 基 板厚さ， $\delta$ : 自由端のたわみ量， $L=75 \mathrm{~mm}$ ：基板長さ, $D:$ 膜厚, $\nu=0.35$ : ポアソン比である. 膜㫗 $D$ の測定 は，めっき付着による基板の質量変化を精密科学天秤
(分解能 0.01mg)で量り, 基板の面積とめっき膜密度 (理 論值 $\left.\mathrm{Zn}: 7.20 \mathrm{~g} / \mathrm{cm}^{3}, \mathrm{Cu}: 8.96 \mathrm{~g} / \mathrm{cm}^{3}, \mathrm{Ni}: 7.90 \mathrm{~g} / \mathrm{cm}^{3}\right)$ の積で 除して算出した. また，電解めっき法はファラデーの 法則に従うことから，質量は通電時間と共に比例的に 増加するものとした。

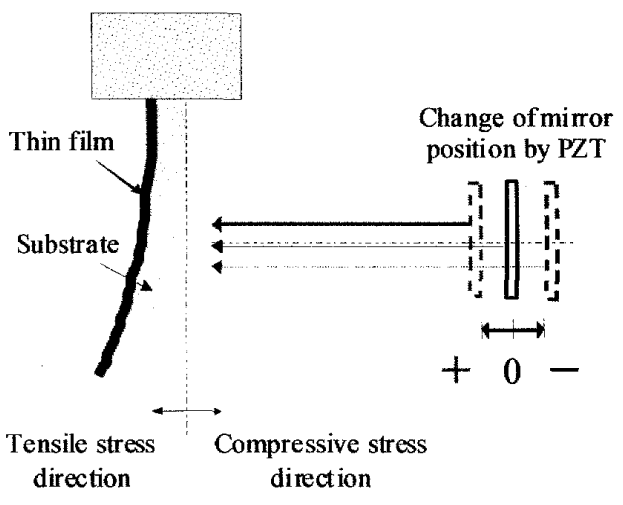

Fig.3 Distinction of displacement (stress) direction using optical path change by PZT

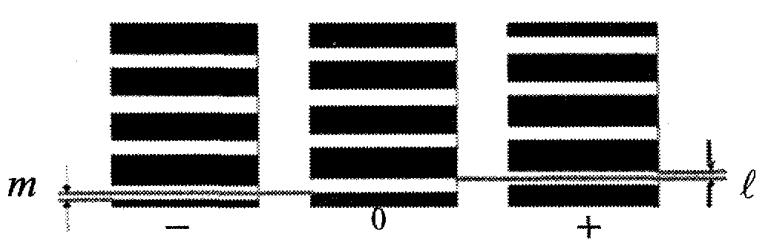

(a) Compressive stress

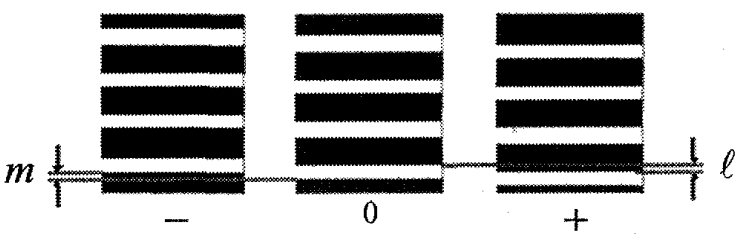

(b) Tensile stress

Fig.4 Relation between distinction of stress direction and movement of interferometric fringes

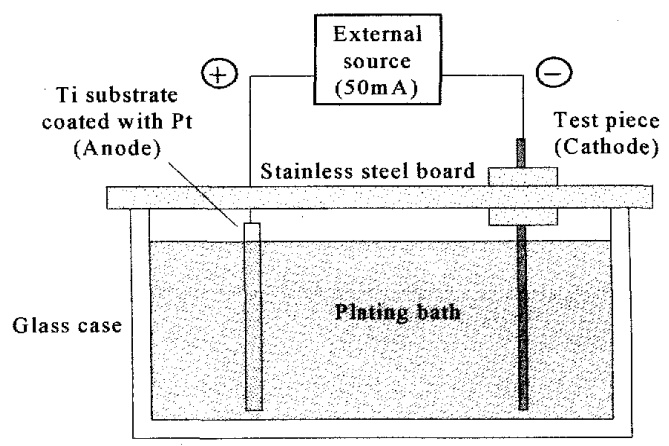

Fig.5 Electroplating bath 
Table 1 Components of Ni-P plating bath

\begin{tabular}{cc}
\hline Components & Mol concentration (mol/L) \\
\hline $\mathrm{NiSO}_{4} \cdot 6 \mathrm{H}_{2} \mathrm{O}$ & 0.10 \\
\hline $\mathrm{NaH}_{2} \mathrm{PO}_{2} \cdot \mathrm{H}_{2} \mathrm{O}$ & 0.30 \\
\hline$\left(\mathrm{CH}_{2} \mathrm{COONa}_{2} \cdot 6 \mathrm{H}_{2} \mathrm{O}\right.$ & 0.10 \\
\hline $\mathrm{C}_{4} \mathrm{H}_{6} \mathrm{O}_{5}$ & 0.10 \\
\hline $\mathrm{C}_{7} \mathrm{H}_{4} \mathrm{NNaO}_{2} \mathrm{~S} \cdot 2 \mathrm{H}_{2} \mathrm{O}$ & 0.01
\end{tabular}

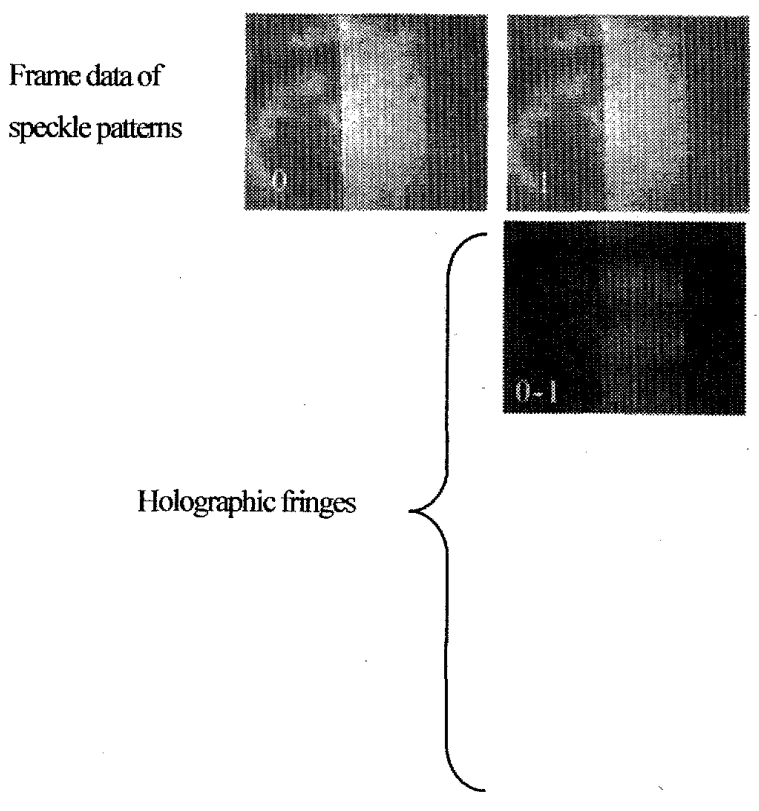

Table 2 Components of various plating baths

\begin{tabular}{|c|c|c|c|c|c|}
\hline \multicolumn{2}{|c|}{$\mathrm{Cu}$} & \multicolumn{2}{|c|}{$Z \mathbf{n}$} & \multicolumn{2}{|c|}{$\mathrm{Ni}$} \\
\hline \multicolumn{2}{|c|}{3.0} & \multicolumn{2}{|c|}{3.0} & \multicolumn{2}{|c|}{4.0} \\
\hline $\mathrm{CuSO}_{4}$ & $0.2 \mathrm{~mol} / \mathrm{L}$ & $\mathrm{ZnSO}_{4}$ & $0.2 \mathrm{~mol} / \mathrm{L}$ & $\mathrm{NiSO}_{4}$ & $0.2 \mathrm{~mol} / \mathrm{L}$ \\
\hline$\left(\mathrm{NH}_{4}\right)_{2} \mathrm{SO}_{4}$ & $0.2 \mathrm{~mol} / \mathrm{L}$ & $\left(\mathrm{NH}_{4}\right)_{2} \mathrm{SO}$ & $0.2 \mathrm{~mol} / \mathrm{L}$ & $\mathrm{H}_{3} \mathrm{BO}_{3}$ & $0.2 \mathrm{~mol} / \mathrm{L}$ \\
\hline
\end{tabular}
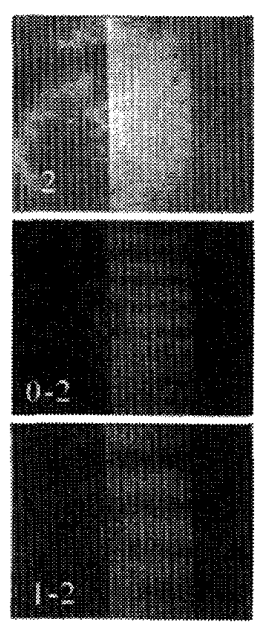

$1-2$

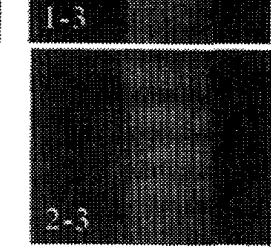

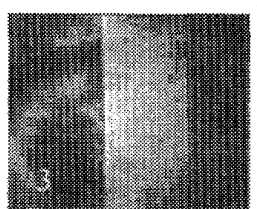
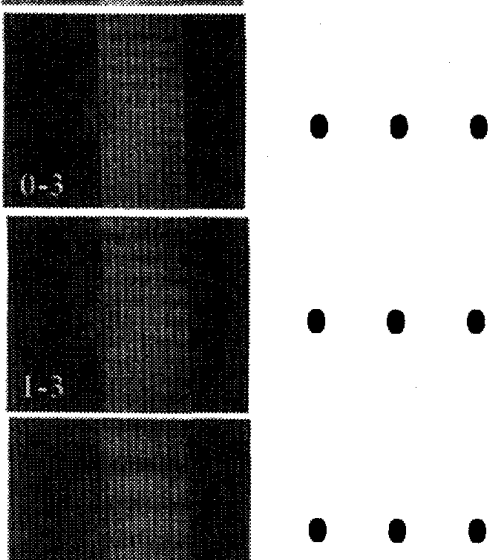

Fig.6 Procedure for making succesive fringe pattems

\section{3. めつき基板表面の内部応力への影残}

3-1 基板表面の前処理と実検条件 基板に直接 めっき膜を生成した場合，めっき膜は基板の結晶格子 に沿って成長 (エピタキシャル成長) する. 本研究で は，はじめにエピタキシャル成長の内部応力への影響 について調べた．実験では銅基板の素地と，基板表面 に表 1 の無電解 Ni-P めっき浴により厚さ約 $0.2 \mu \mathrm{m}$ の アモルファス膜を施してエピタキシャル成長を無くし た基板を準備した。 なお，アモルファス膜生成による 残留応力を調べるため, 膜の生成後と, 約 1 時間経過 後の状態について，ホログラフィ干渉法により変形を 調べたところ，変形による干渉縞は生じなかった，乙 たがって，本実験では前処理が基板に及ぼす残留応力 の影響は無視できるものと考えた.

そこで，表2の Znめつき浴について，基板表面が 内部応力に及ぼ寸影響を調べた。 なお，添加剂は内部 応力に影響を及ぼしやすいことから，めっき浴から取
り除いて単純な組成とした.

3.2 実験結果と考察 図6はぬっき膜生成中の 基板の動きを 1 秒間隔で連続して記録したスペックル パターン画像 $(1,2,3, \cdots)$ と, それらの減算処理画 像 $(0-1,0-2,0-3, \cdots, 1-2,1-3, \cdots, 2-3, \cdots)$ であ る. 本実験では，記録したフレームについて時間間隔 を種々に変えて減算処理をしてホログラフィ干涉縞を 作成し，その中で縞解析に適する縞密度の干涉縞を選 んで用いることができる. 図6の害験では，4秒間隔

$(0-4,1-5, \cdots)$ 以上になってくると, $2 つ$ 処理画 像間での変形量が多くなってきて干渉縞が密になる. その結果, 明暗の間隔がカメラの分解能に近づくと, 縞の判断が困難となり解析できない，図 6 の0,1, 3 のスペックルパターン画像には, 光学素子等による回 折ノイズが多く見られるが，二つの画像の差を取ると， ノイズ成分は减少されて変形を表す干涉縞のみが鮮明 に現れる．また，本実験のようにめつき基板の全視野 
測定を実施することにより，今回の得られた干涉縞が いずれも平行であることから，実験における試料の取 り付け不備やめっき浴の流扎等の基板たわみへの影響 がほとんど現れていないことも推察できる.

内部応力の算出には, 干涉縞に 1 縞当たりの変位量 $0.3 \mu \mathrm{m}$ を掛けて, 自由端のたわみ量を算出寸る. なお, 実験はそれぞれの条件で 5 回実施した結果，同じよう な傾向を示したので，代表的な結果について述べた。 図7にZ゙nめつきにお汁る片持ちはりのたわみ量と膜 厚の関係を示寸．図中の実線は前処理無しの銅基板に めつき膜を生成した場合で，破線は前处理によるアモ ルファス状態の表面にめつき膜を生成した場合である. どちらも単調に土縮方向に変形しているが, アモルフ アス層を有寸る方は, 初期の変化量が大きい. しかし, 膜厚が大きくなると両者のたわみ量は同じ程度になっ た. 図7 の結果を式 (3)に代入して算出した内部応力

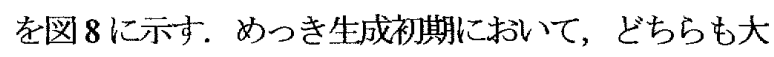
きな圧縮応力が発生する. 特にアモルファス層の場合 は, その変化が急激である. その後は両者とも応力が 緩和する方向に戻るが, 膜厚約 $1.5 \mu \mathrm{m}$ でほぼ同じ值に なった. 図9(1),(2)に表面のX線回折とSEM の観察結 果を示す. 図9(1)の(a)の前処理なしでは結晶面がラン ダムに配向しているのに対し，(b)のアモルファス面の 場合は結晶が(002)面に優位に配向した.このことは, 図9(2)のSEM 写真において, (a)の前処理なしでは銅 基板の結晶粒界（図中の白線）によってめっき膜の配 向が変化するが，アモルファス面では全面に六角形の 結晶面が見られることからもわかる. したがって, 図 8 のめっき生成初期の圧縮応力の変化量の差は, めっ き膜の配向に影響されていることが推察できる.

\section{4. 各種めつき膜と内部応力の挙動}

市場で一般に幅広く使われ，めっき生成が容易な $\mathrm{Cu}$, $\mathrm{Zn}, \mathrm{Ni}$ の各種めっき浴について, めっき膜生成中の内 部応力挙動の測定と, そのときの表面・断面の観察を おこなった. なお，めつき基板には素地の影響を無く すために, 銅基板に Ni-P $O$ 無電解めっきによる前処理 を施してアモルファス面とした，各めっき浴の組成は 前述の表 2 に示寸。上段からめっき膜の種類, $\mathrm{pH}$, 金 属塩，pH緩衝郕を示寸， pHは浴がもつとも安定する ときの值で, 金属塩恃全て硫化物で統一した.

実験ではめっき浴について，浴中に置いた銅基板の スペックルパターンの変化を 1 秒閒隔で記録した. 図 10 (図 8 のアモルファス面の部分) に Zn めっき膜の 内部度力の算出結果走寸．また図中の各膜厚(a),(b), (c)でのSEMによる表面観察の結果を図 11 に示す. 図

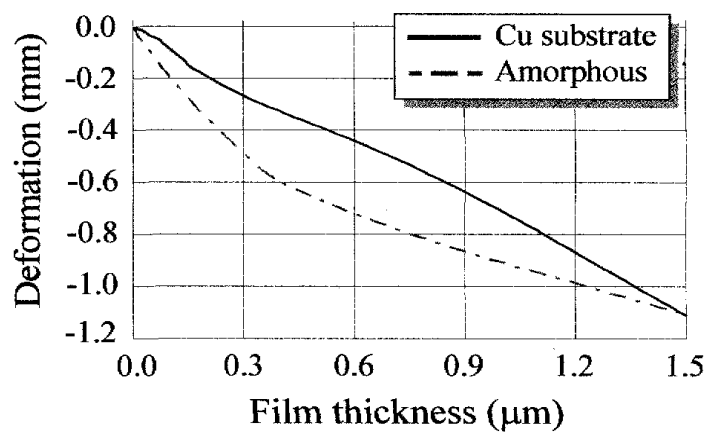

Fig.7 Relation between defomation and film thickness for Zn plating

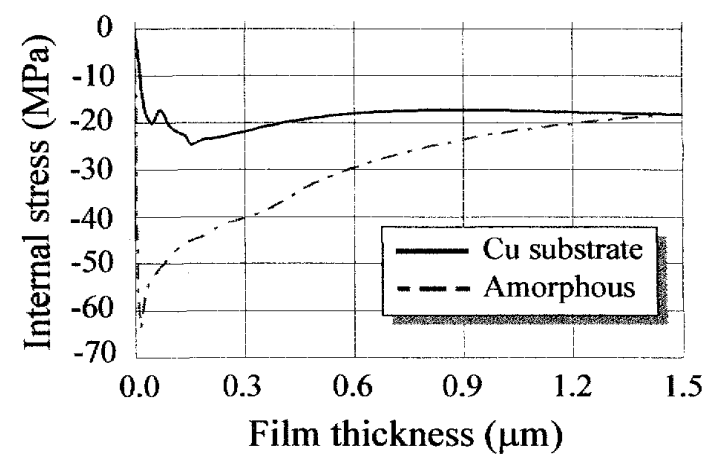

Fig.8 Relation between internal stress and film thickness for $\mathrm{Zn}$ plating

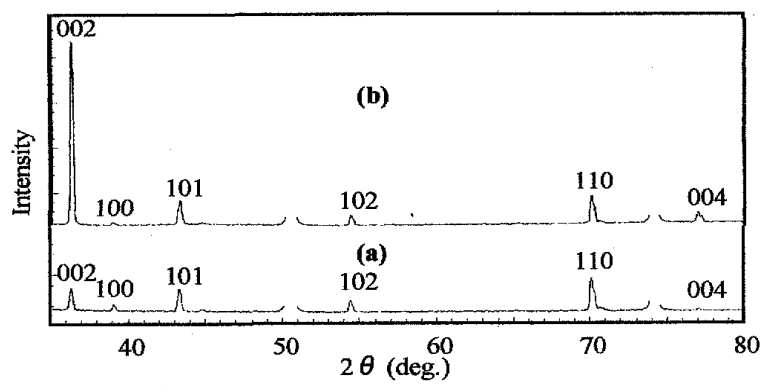

(1) $\mathrm{X}$-ray diffraction pattern

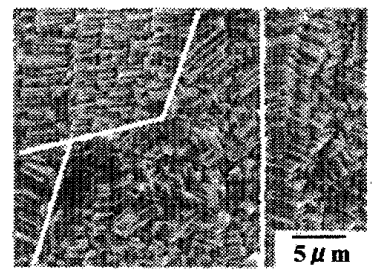

(a)

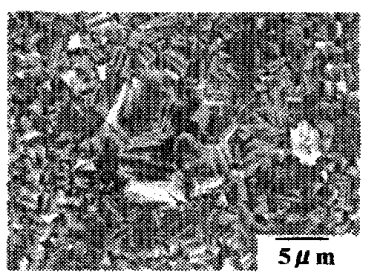

(b)
(2) SEM images

Fig.9 X-ray diffraction pattern and SEM images for $Z n$ plating

(a) Epitaxial growth of plating on Cu substrate

(b) Zn plating on amorphous substrate 
10 のめき初期の急激な压樎方向への応力変化(a)で は，図11より結晶粒子が全面に析出している.一方, 応力がゆっくりと回愎している膜厚(b), (c)では, 粒子 一-正の径が大きく成長している．したがって，Zn めつきでは膜の生成開始から基板全面に結晶粒子が析 出し，これらの結晶粒界において粒子同士が押し合う ことで圧縮応力が発生すると思われる。

$\mathrm{Cu}$ めっき内部応力の測定結果を図 12 に，また図 12 の各膜㫗(a),(b),(c)の SEM による表面㓋察の結果を 図 13 に示す.めつき初期では内部応力が比較的ゆっく りと引張り方向に変化して最大值となり，その後は圧 縮方向に変化し，再び最大值をとると再び引張り方向 に変化した．膜㫗(a),(b)では粒子仕基板上でまばらに 合体・成長している様子がわかる，膜厚(c)では，ほぼ 基板全面に粒子膜が密集し，結晶粒界を形成した. $\mathrm{Cu}$ めつきの場合，はじめに粒子同士の合体により応力が 発生し，その後，成長した粒子が結晶粒界を形成し， 結晶粒界において粒子同士が押し合うことで压縮応力 に変化すると思われる.

$\mathrm{Ni}$ めつきの部応力を図 14 に示し，TEMによる断 面観察の結果を図 15 に示す，断面図より Ni めつき浴 では粒径約 $200 \mathrm{~nm}$ 程度の微細な粒子が膜厚方向に密 集して析出していることがわがる. Ni めつきでは粒子 が析出後, 直ぐに結晶化して体積収縮が起こり, 引張 応力が発生すると思われる.

\section{5. 結 言}

本研究では，電解めつき浴として一般に使用されて いる Zn, Cu, Ni めっきについて，浴を単純化して，成 膜中の内部応力の挙動について TV ホログラフィ干渉 法を用いて調べた．なお，はじめに基板表面の影響に つい考察し，次に各種めつき浴の内部応力の挙動に つて，そのときのめつき表面・断面観察を通して考 察した。 以下に本研究加ら得られた知見を示す。

(1) 内部応力はめっき生成のごく初期に急激に変化 し，その後は緩や力汇変化する.

（2）めつきの生成初期の内部応力は，基板表面がアモ ルファス面の場合，素地基板に比べて大きく急激 に変化するが, 膜昌が大きくなると両者の差は小 さくなる.

(3) Zn めっきの内部応力の発生は, 結晶粒子つ一つ の成長によって起こる.

（4） $\mathrm{Cu}$ めっき内部応力の発生は，めつき生成初期 では結晶粒子同士の合体・吸収が支配的であり， 連続膜になると結晶粒界における結晶同士の押し 合いが支配的に作用する. (a)

(b)

(c)

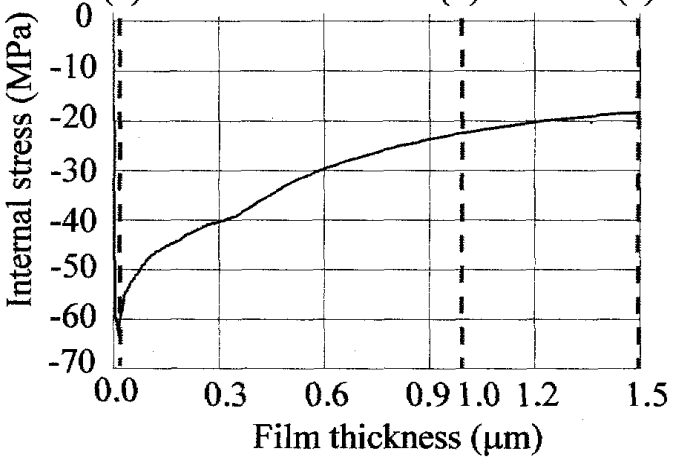

Fig.10 Relation between internal stress and film thickness for Cu plating

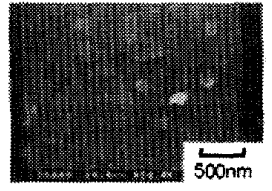

(a)

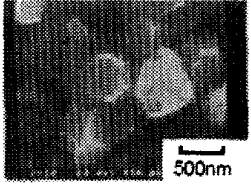

(b)

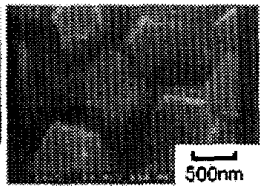

(c)
Fig.11 SEM images for $Z n$ in Fig.8

(a) (b)

(c)

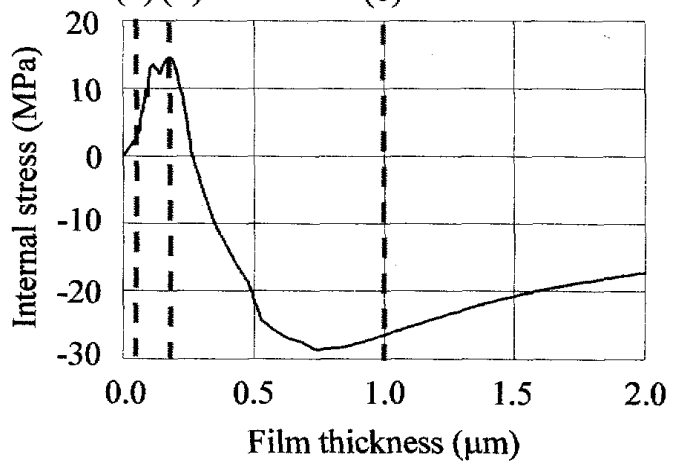

Fig.12 Relation between internal stress and film thickness for Cu plating
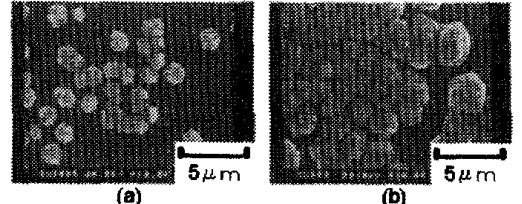

(b)

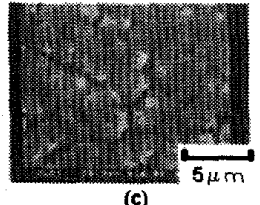

(c)
Fig.13 SEM images of Cu plating on the substrate 


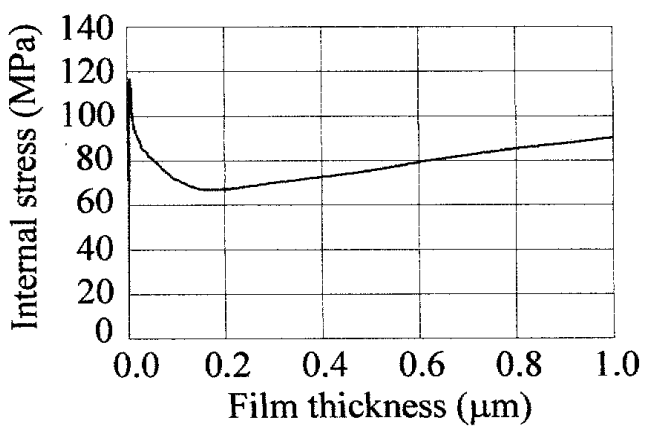

Fig.14 Relation intemal stress and film thickness for Ni plating

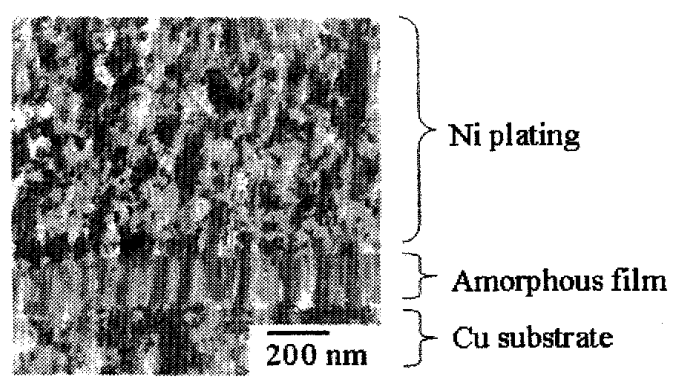

Fig.15 Cross-sectional TEM image of Ni plating on amorphous substrate

(5) Ni めっきの内部応力の発生は, めつき粒子の結晶 化が支配的作用寸る。

なお，内部念力の挙動要因としては，金属塩，添加 剂により水素, 硫黄, 炭素が発生し，これらが複雑に 絡み合って膜成長に影響することが考えられる.した がって，めっき内部応力のメカニズムを考える上にお いては，さらなる微少元素の影響について調べること が重要となる.

\section{考 文 献}

(1) The Surface Finishing Society of Japan, Surface finishing engineering, (2005), p.1, Nikkan Kogyo Shimbum Ltd (in Japanese).

(2) TanakaK, Intemal Stress in Surface Treated Layers, (1992),p.624, The Journal of the Surface Finishing Society of Japan, (in Japanese), Hyomen Gijutsu.
(3) Galvanization Society, The next generation plating technology, (2004), P.1., Nikkan Kogyo Shimbun Ltd, (in japanese)

(4) Koch.P., The Intrinsic Stress of Polycrystalline and Epitaxial Thin Metal Films, J.Phys, Condens Matter, Vol.6, (1994), pp.9519-9550.

(5) Ahmed.S., Ahmed.T.T., O'Grady.M., Nakahara.S., and Buckley.D.N., Stress and Microstructure in Electrodeposited Copper Nanofilms by Substrate Curvature and In-site Electrochemical AFM Measurements, ECS Transactions, Vol.11, No.24, (2008), pp.1-12.

(6) Klokholm.E., An Apparatus for Measuring Stress in Thin Films, The Review of Scientific Instruments, Vol.40, No.8, (1969), pp.054-1056.

(7) Horikoshi.H., and Tamura.N., Intemal Stress and Electrical Resistivity of Evaporated Antimony Films, Japanese Journal of Applied Physics, Vol.2,No.6, (1963), pp.328-336.

(8) Maser.J.R., Buhl.R. and Pulker,H.K., Mechanical Stresses in Dielectric Films Measured with a New Optical Monitoring Devices, Proc. $7^{\text {th }}$ Intern. Vac. Congr \& $3^{\text {nd }}$ Int.Conf. Solid Surfaces Vienna, (1977), pp.1761-1765.

(9) Ennos.A.E.: Stress Developed in Optical Film Coatings, Appl. Opt., Vol..5, Nol, (1996), pp.51-61.

(10) Kakunai.S., Hayashihara.H., In-situ Measunement of Intemal Stress in Electroless Plating by Television Holographic Interferometry, Applied Mechanics and Materials Vols.3-4, (August 2005), pp.65-70.

(11) Fukumuro.N., Yamazaki.M., Ito.K, Ishihara.H., Kakunai.S., Yae.S., and Matsuda H, In site Measurement of Intemal Stress in Electroless Deposited Copper Film by Television Holographic Interferometry, Electrochem, Solid-State Lett., Vol.10, (2007), pp.14-15.

(12) Davis.J.C. and Buckberry.C.H., Optical Methods in Engneering Metrogy, edited by Williams.D.C., (1993), p.275, CHAPMAN \& HALL

(13) Stoney.G.G., The Tension of Metallic Films Deposited by Electrolisis, Proc. Roy.Soc., A82, (1909), pp.172-175.

(14) Brenner.A., and Senderoff.S., Calculation of stress in electrodeposites from the curvature of a plated strip, J.Research National bureau of Stenderds, Vol.42,(1949), pp.1065-123.

(15) N.N.Davidson.N.N., Measurement of Residual Stress in Electrolytic Deposits, Sov. Phys. Solid State Vol..2,(1961), pp.2595-2598. 